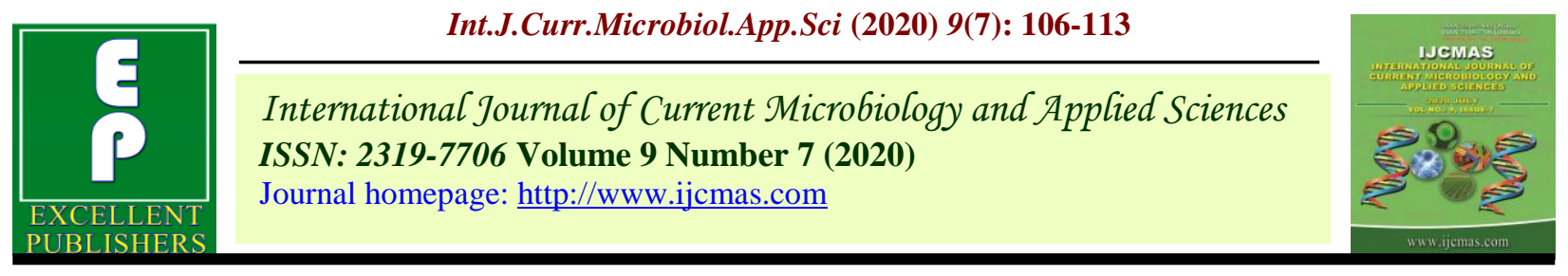

Original Research Article

https://doi.org/10.20546/ijcmas.2020.907.012

\title{
Substrate Comparison for Yield Maximization in White Milky Mushroom (Calocybe indica)
}

\author{
A. Sangeetha* and K. Rajappan \\ Department of Plant Protection, Horticultural College and Research Institute for women, \\ TNAU, Navalur Kuttapattu, Tiruchirappalli-620 027, India \\ *Corresponding author
}

\begin{tabular}{|l|}
\hline Ke y w o r d s \\
$\begin{array}{l}\text { Spawn, Milky } \\
\text { mushroom, } \\
\text { Biological } \\
\text { efficiency, Fruiting } \\
\text { body, Pileus, Stripe }\end{array}$ \\
\hline Article Info \\
\hline $\begin{array}{l}\text { Accepted: } \\
\text { 05 June 2020 } \\
\text { Available Online: } \\
\text { 10 July } 2020\end{array}$ \\
\hline
\end{tabular}

A B S T R A C T

The present investigation was carried out to find the effect of different substrates such as Paddy straw, sorghum trash, maize trash, coconut coir pith, Sugarcane baggase and cotton waste on growth and yield of milky mushroom. Days for spawn running (DFSR), days for pin head formation (DFPH), number of pin head initiation (NoPI), number of fruiting bodies (NoFB) and days for first harvest (DFFH) were superior with the paddy straw. Among different substrates used, paddy straw was superior and recorded the highest yield $(752.32 \mathrm{~g})$ whereas the sugarcane baggase recorded the lowest yield (402.08 g). Biological efficiency has significantly varied and found to be the highest when paddy straw (150.46\%) was used as substrate. Sorghum and maize stalks were on par in their biological efficiency while the least was recorded with sugarcane baggase $(80.41 \%)$.

\section{Introduction}

Mushrooms are commonly called as macrofungi as their fruiting bodies are large enough to be seen with naked eyes. Mushroom cultivation represents solid-state fermentation which is an important microbial technology in which crop residues could be used as a substrate to produce a valuable food that is rich in protein. Protein conversion efficiency and mushroom yield are more compared to plant and animal sources. It is an eco-friendly activity and reduce the carbon foot print (Krishnamoorthy and Priyadharshini, 2016). Mushrooms provide a rich addition to the diet in the form of protein, carbohydrates, valuable salts, minerals and vitamins. As food, the nutritional value of mushrooms lies between meat and vegetables. Like other vegetables it contains about 90 per cent moisture and is basically low calorie food (25 - 30 calorie / $100 \mathrm{gm}$ fresh weight). Mushroom farming is commonly practiced in more than 100 countries. India made rapid progress in the growth of mushroom industry by cultivating the tropical and subtropical 
mushrooms. The annual turnover of fresh mushrooms in India is about 1.13 lakh tonnes with Punjab, Uttarakhand and Haryana as the leading states (Thakur and Singh, 2014).

Milky mushroom (Calocybe indica) has become the third commercially grown mushroom in India after button and oyster mushrooms. This mushroom is also called white summer mushroom as it grows well during the summer months. Similar to Volvariella species, this mushroom is an ideal candidate for hot weather cultivation. This mushroom is gaining popularity due to its attractive robust, white sporocarps, fleshy, umbrella like structure with longer shelf life and delicious taste (Kumar et al., 2013). Mature sporophore of Calocybe indica contains $4 \%$ soluble sugars, $2.9 \%$ starch and 7.4\% ash (Alam et al., 2010). Calocybe indica has a higher biological efficiency (> 90\%) and produce attractive white sporophore with excellent shelf life. These qualities make cultivation of milky mushroom most suitable in tropical and sub-tropical climate (Senthilnambi et al., 2011). This mushroom has an immense potential in production in the plain region of India due to its better temperature tolerance $\left(30-35^{\circ} \mathrm{C}, \mathrm{RH}\right.$ 70$80 \%)$.

Usually, a wide range of diverse cellulosic substrates are used for cultivating mushrooms. Calocybe indica has been cultivated on a wide range of agrowastes, garden wastes and forest wastes (Dakshayini and Mallesha, 2018). The production of milky mushroom is highly promising in India. There is no need to compost the substrate for its cultivation as the mycelium can degrade the cellulose, hemicelluloses and lignin by secretion of various extracellular enzymes. In spite of this, only a small fraction of the agricultural waste like paddy straw, maize and sorghum stalk, sugar cane baggase and cotton waste are being utilized in Tamil Nadu which causes environmental problems and incurs disposal cost to the farmers.

As it is revealed from the literature, not much work has been done on $C$. indica as it is new introduction to mushroom world. Therefore, efforts are being made in this study to identify the cheaper locally available substrate into more profitable products using solid-state fermentation to enhance the productivity of milky mushroom.

\section{Materials and Methods}

The study was carried out in the farmers mushroom house, Neithalur colony village Tiruchirappalli, Tamil Nadu, India during March - May, 2020. The experiments were laid out in the Complete Randomized Design (CRD) with six treatments $\left(\mathrm{T}_{1}-\right.$ Paddy straw, $\mathrm{T}_{2}$ - sorghum stalk, $\mathrm{T}_{3}-$ Maize stalk, $\mathrm{T}_{4}-$ Coconut coir pith, $\mathrm{T}_{5}-$ Sugar cane baggase and $\mathrm{T}_{6}-$ Cotton waste) and replicated four times to cultivate the milky mushroom. The mother spawn was obtained from Department of Plant Pathology, TNAU, Coimbatore.

\section{Preparation of spawn}

In the present study, mother spawn of $C$. indica (APK-2) was prepared from pure culture. Commercial spawn was then prepared by using softened sorghum grains in polyethylene bags $\left(9^{\prime \prime} \times 13^{\prime \prime}-150\right.$ gauge) @ $500 \mathrm{~g}$ grain $/ \mathrm{bag}$. Thereafter, these bags were sterilized at $15 \mathrm{lbs} . / \mathrm{sq}$. inch for 2 hours.

After cooling, the bags were aseptically inoculated with $15 \mathrm{~g}$ of mother spawn in a laminar airflow chamber and incubated at 30 $\pm 2^{\circ} \mathrm{C}$. During the period of incubation, the bags were frequently examined for any type of contamination. Bags showing white and uniform mycelial growth covering all the grains were used for bed preparation. 
Preparation of mushroom bed and spawning

Substrates were chopped into small pieces of $4-5 \mathrm{~cm}$ and then subjected to hot water treatment containing formaldehyde $(250 \mathrm{ppm})$ and Carbendazim (100 ppm) to sterilize for 12 hours. The mouth of the hauze was covered with polythene sheet to avoid the release of gases coming out from formaldehyde. Then, excess water was drained off and dried by spreading over polythene sheet for 1 to 1.5 hours. The moisture content of the straw was kept at 65-70 per cent. It was tested by palm method by squeezing the handful of straw. Then the straw was ready for spawning.

Spawning is a technique of introducing spawn into the substrate with the aim of achieving rapid growth for the production of sporophores (fruiting bodies). Transparent Polypropylene bags of $60 \mathrm{~cm} \times 30 \mathrm{~cm}$ of 150 gauge thickness were used for cultivation. The bottom of the bag was tied with a rubber band to make a cylindrical shape to the bed. Spirit dipped cotton is used to sterilize the bag and then it was turned over to make the tied portion to be inside. The beds were prepared by using $0.5 \mathrm{~kg}$ substrate on dry weight basis and $125 \mathrm{~g}$ of spawn / bed in alternate layers. Altogether five layers of substrate and four layers of spawn were kept and finally the bag was tied at the top and 10-12 holes were made at random in the polythene bag. The lower end corners were cut to drain off the excess water. Thereafter, the necks of the bags were closed with rubber bands. The spawned bags were then kept in the hanging nets placed in the mushroom house, where the temperature of $25-35^{\circ} \mathrm{C}$ and relative humidity of $80-90$ per cent were maintained for spawn running. This was done by frequently sprinkling water on the walls, floor and by using mist fan. The spawn run, which refers to the growth of the spawn on the substratum, took 10-15 days. After complete colonization of the substrate by mushroom mycelium, casing was done.

\section{Casing of the bags and pin head formation}

After spawning, casing was done using clay loam soil ( $\mathrm{pH}$ 8.0). The material was slightly moistened after casing and then applied to create casing layer thickness of $2.0 \mathrm{~cm}$ uniformly over the substrate surface. Before use, the casing material was autoclaved at 15 lbs psi for 60 minutes. After casing, beds were kept on racks in cropping room for fruiting. The temperature and relative humidity for fruiting were kept $30-35^{\circ} \mathrm{C}$ and 80-85 per cent, respectively and the relative humidity was maintained by using mist fan. After casing of beds, ventilation was reduced. The fruiting bodies were protected from direct sunlight and diffused light was allowed to induce fruiting bodies. Watering was done two times a day by a hand sprayer. After 8-10 days of casing, numerous needle-shaped pin heads started appearing, and within 6-10 days some of them matured into large-sized sporophores, ready for harvesting.

\section{Harvesting of sporophores}

Watering was withheld a day before harvesting. Mature sporophores were harvested when the edges of the cap (pileus) begin to dry or show yellowness. Picking was done by twisting the stipe clockwise and anticlockwise so that the surrounding young developing mushrooms were not damaged. The sporophore count was recorded for each flush. In all, three flushes were harvested from the same bed at an interval of 10-15 days. Thus, the total cropping period varied from 55-60 days.

\section{Characteristics of sporophore}

The freshly harvested sporophores were immediately weighed with the help of an electrical balance and were expressed in grams. Days for spawn run (DFSR), days for pin head formation (DFPH), days for first 
harvesting (DFFH), number of pin head initiation (NoPI), number of fruiting bodies (NoFB) and total yield were recorded. The sporophores collected from each bag were also measured for their size, which included a diameter and size of the pileus (cap), length, size and diameter of the stipe (stalk), with the help of thread and expressed in centimetres. Pileus to stipe ratio was estimated by dividing the diameter of pileus with length of the stipe.

\section{Yield and biological efficiency}

The cumulative yield for each substrate and all replicates was recorded by summing up the fresh weight of pickings. Biological efficiency (BE), is the ability of mushrooms to convert the substrate contents into fruiting bodies (Chang and Miles, 1989).

Biological Ef ficiency $(\%)=\frac{\text { Fresh weight of mushroom yield }(\mathrm{g})}{\text { Dry weight of substrate used }} X 100$

\section{Statistical analysis}

The results were presented as mean value of trilicates \pm standard deviation (SD). Statistical analysis was performed using the one-way analysis of variance (ANOVA) such as growth behaviour; different morphometric characters; yield and biological efficiency on these tested substrates. Means of results for each experiment was compared using the Duncan's Multiple Range Test $(p<0.05$ confidence levels). SPSS version 21 for windows (IBM SPSS Inc., Chicago, IL) statistical software was used for all statistical analysis.

\section{Results and Discussion}

\section{Growth and yield attributes}

The production of mushroom largely depends on substrate in which it is grown. Data given in Table 1 depicts the influence of substrates on the growth behaviour of milky mushroom including time required for complete spawn run, pinhead formation and first harvest. The substrates have significantly affected the yield attributes such as spawn run (days), pinhead initiation (days) after casing, number of pinheads per bed, number of sporophore per bed, yield per bed (g) and biological efficiency. Paddy straw $\mathrm{T}_{1}$ as a substrate resulted into shorter period (18.04 days) followed by Maize $\mathrm{T}_{3}$ (19.87 days) for DFSR. Sorghum and cotton waste were on par in the DFSR. The longest period (22.14 days) was observed under sugarcane baggase. In the present investigation amongst the various spawn substrates evaluated, paddy straw was found to be the best spawn substrate for early spawn run for completing mycelia growth. The variation in the colonization of different substrates could be due to the variation in the amount of moisture observed during boiling, which is one of the critical factors responsible for mycelia growth (Kumar et al., 2013). Perusal of data reveals that similar to the DFSR, DFPH also varied significantly among the substrates. Paddy straw took lesser period (9.76) whereas sugarcane baggase recorded more days (13.16) for pin head formation. Sorghum and maize strands were on par with their results. Several workers had reported the superiority of paddy straw as a substrate for the cultivation of milky mushroom (Krishnamurthy and Muthusamy, 1997; Biswas and Singh, 2009; Pani, 2010).

Average number of pin heads formed directly influences the sporophore yield. The substrates almost behaved similarly on their NoPI and NoFB. Though higher number of pin heads was initiated with maize as substrate, ultimately the number of sporphores was higher with paddy straw as substrate. Inspite of higher pin heads initially under sugarcane baggase, the sporophores produced was very less (6.34). The maximum number of sporophores (10.19) per bed was harvested in $\mathrm{T}_{1}$ (paddy straw) which was 
found to be significantly superior to other treatments. This was followed by 9.26 in $\mathrm{T}_{1}$ (Maize) and $\mathrm{T}_{2}$ (Sorghum straw). The presence of the right proportion of $\alpha$ cellulose, hemi-cellulose, pectin and lignin was the probabale cause of higher rate of pin head formation under paddy straw as a substrate. Minimum number of sporophores (6.34) was harvested in $\mathrm{T}_{5}$ (Sugar cane baggase). The variation in the colonization in different substrate could be due to the variation in the amount of moisture observed during boiling, which is one of the critical factors responsible for mycelial growth (Gitte et al., 2014). Paddy straw as a substrate resulted into more number of fruiting bodies (NoFB), lesser days for first harvest (13.17 days) and with higher average weight (73.83 g) of milky mushroom.

The yield and biological efficiency of milky mushroom under different substrate is illustrated in the Fig 1. The maximum yield $\left(752.32 \mathrm{~g}\right.$ ) per bed was recorded in $\mathrm{T}_{1}$ (paddy straw) whereas the minimum yield (402.08 g) per bed was recorded in $\mathrm{T}_{5}$ (sugarcane baggase). It is possible that variations detected in cropping period on different agrowastes may be due to the environmental variations (temperature, humidity and light arrangements) or due to specific nutritional requirements of the cultivated mushroom (Lakshmipathy et al., 2011). Substrates containing glucose, fructose, trehalose produced the highest number of primordial whereas abnormal fruiting bodies were produced in glycerol, xylose, sucrose and fructose. Maximum biological efficiency $(150.45 \%)$ was recorded with the paddy straw as substrate. The biological efficiency was above 100 for the sorghum, cotton waste and maize as substrate. Very poor biological efficiency (80.42) was recorded with sugarcane baggase as substrate. Similar results were reported by Senthilnambi et al., (2011), Doshi et al., (1989) and Lakshmipathy et al., (2011) on the biological efficiency of various mushrooms in different agrowastes.

\section{Sporophore characteristics}

Maximum weight of sporophore (73.83 g) was recorded in paddy straw as substrate followed by maize (69.64). the sporophore weight was minimum with coconut coirpith (62.35) which was on par with sugarcane baggase (63.42 g) (Table 2). The results obtained in the present study for APK-2 strain are in accordance with the findings of many other researchers who also observed high yield and high biological efficiency of APK-2 on these standard agrowastes as compared to other lignocellulosic substrates (Krishnamoorthy and Muthusamy, 1997; Rawal and Doshi, 2014; Selvaraju et al., 2015; Dakshayini and Mallesha, 2018).

Table.1 Performance comparison of different substrates for milky mushroom production

\begin{tabular}{|l|l|l|l|l|l|}
\hline Agro waste Substrates & DFSR & DFPH & Avg. NoPI & Avg. NoFB & DFFH \\
\hline T $_{\mathbf{1}}$ : Paddy straw & $18.04 \mathrm{a}$ & $9.76 \mathrm{a}$ & $17.86 \mathrm{ab}$ & $10.19 \mathrm{~d}$ & $13.17 \mathrm{a}$ \\
\hline $\mathbf{T}_{\mathbf{2}}$ : Sorghum stalk & $20.41 \mathrm{c}$ & $10.15 \mathrm{~b}$ & $17.63 \mathrm{a}$ & $8.97 \mathrm{c}$ & $13.86 \mathrm{a}$ \\
\hline $\mathbf{T}_{\mathbf{3}}$ : Maize stalk & $19.87 \mathrm{ab}$ & $10.84 \mathrm{bc}$ & $19.72 \mathrm{~cd}$ & $9.26 \mathrm{~cd}$ & $14.93 \mathrm{~b}$ \\
\hline $\mathbf{T}_{\mathbf{4}}$ : Coconut coirpith & $21.36 \mathrm{~d}$ & $12.05 \mathrm{e}$ & $18.17 \mathrm{bc}$ & $7.85 \mathrm{~b}$ & $17.52 \mathrm{~d}$ \\
\hline T $_{\mathbf{5}}$ : Sugarcane baggase & $22.14 \mathrm{de}$ & $13.16 \mathrm{f}$ & $18.36 \mathrm{bc}$ & $6.34 \mathrm{a}$ & $19.29 \mathrm{e}$ \\
\hline $\mathbf{T}_{6}:$ Cotton waste & $20.86 \mathrm{c}$ & $11.18 \mathrm{~d}$ & $17.63 \mathrm{a}$ & $8.06 \mathrm{bc}$ & $16.34 \mathrm{c}$ \\
\hline CD $\mathbf{( P = 0 . 0 5 )}$ & 0.92 & 0.21 & 0.56 & 1.04 & 0.79 \\
\hline
\end{tabular}

Means in a column followed by a same latter are not significantly different from each other according to DMRT $(\mathrm{P}=0.05)$. 
Table.2 Effect of different substrates on milky mushroom morphological parameters

\begin{tabular}{|c|c|c|c|c|c|c|c|c|}
\hline \multirow[t]{2}{*}{ Agro waste Substrates } & \multirow{2}{*}{$\begin{array}{c}\text { Avg.wt. of } \\
\text { sporophore (g) }\end{array}$} & \multicolumn{3}{|c|}{ Pileus characters } & \multicolumn{3}{|c|}{ Stipe characters } & \multirow{2}{*}{$\begin{array}{c}\text { Pileus to } \\
\text { stipe } \\
\text { ratio }\end{array}$} \\
\hline & & $\begin{array}{l}\text { Diameter } \\
(\mathrm{cm})\end{array}$ & $\begin{array}{l}\text { Thickness } \\
(\mathrm{cm})\end{array}$ & $\begin{array}{l}\text { Weight } \\
\text { (g) }\end{array}$ & $\begin{array}{l}\text { Length } \\
(\mathrm{cm})\end{array}$ & $\begin{array}{l}\text { Thickness } \\
(\mathrm{cm})\end{array}$ & $\begin{array}{l}\text { Weight } \\
\text { (g) }\end{array}$ & \\
\hline$T_{1}:$ Paddy straw & $73.83 \mathrm{e}$ & $8.19 \mathrm{~d}$ & 2.14de & $39.92 \mathrm{e}$ & $8.39 c$ & $2.71 \mathrm{~cd}$ & $33.91 d$ & $0.98 b c$ \\
\hline$T_{2}$ : Sorghum stalk & $66.91 b$ & $8.01 \mathrm{~d}$ & $1.88 \mathrm{bc}$ & $35.23 b c$ & $7.65 b$ & $2.42 b c$ & $31.68 b c$ & $1.04 \mathrm{c}$ \\
\hline $\mathbf{T}_{3}:$ Maize stalk & $69.64 d$ & $7.93 \mathrm{bc}$ & $2.06 \mathrm{~d}$ & $36.34 \mathrm{~cd}$ & $8.24 \mathrm{c}$ & $2.35 b c$ & $33.30 \mathrm{~d}$ & $0.96 b$ \\
\hline $\mathbf{T}_{4}$ :Coconut coirpith & $62.35 \mathrm{a}$ & $6.97 \mathrm{~b}$ & $1.76 b$ & $33.78 \mathrm{a}$ & $8.73 \mathrm{~cd}$ & $1.95 \mathrm{ab}$ & $28.57 \mathrm{a}$ & $0.79 a$ \\
\hline$T_{5}:$ Sugarcane baggase & $63.42 \mathrm{a}$ & $6.08 \mathrm{a}$ & $1.44 \mathrm{a}$ & $33.41 \mathrm{a}$ & $6.28 \mathrm{a}$ & $1.71 \mathrm{a}$ & $30.01 b$ & $0.96 b$ \\
\hline$T_{6}:$ Cotton waste & $67.14 b c$ & $7.12 b$ & $1.71 b$ & 34.19ab & $7.89 b$ & $1.69 \mathrm{a}$ & $32.95 \mathrm{c}$ & $0.90 \mathrm{~b}$ \\
\hline $\mathrm{CD}(\mathbf{P}=0.05)$ & 2.12 & 0.23 & 0.09 & 1.56 & 0.43 & 0.37 & 0.81 & 0.08 \\
\hline
\end{tabular}

Fig.1 Influence of agro-wastes on fruiting yield and biological efficiency of Milky mushroom

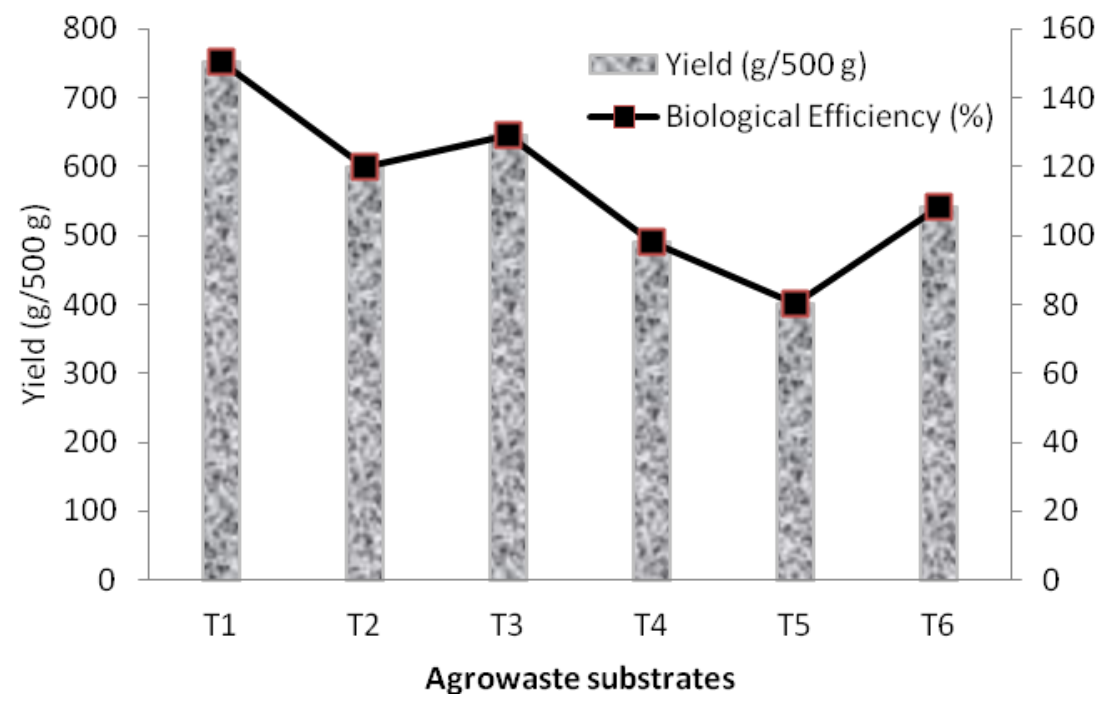

$\mathrm{T}_{1}$ (paddy straw) recorded maximum diameter of pileus $(8.19 \mathrm{~cm})$ followed by sorghum straw $(8.01 \mathrm{~cm})$. Coconut coirpith $(6.97 \mathrm{~cm})$ and sugarcane baggase $(6.08 \mathrm{~cm})$ were poor in sporophore generation with better pileus diameter (Table 2). Senthilnambi et al., (2011) reported that out of maize seed, cotton seed, sorghum seed, horsegram, blackgram, cowpea and ragi seed as spawn base, sorghum seed was the best followed by Ragi seed for milky mushroom spawn production. Alsowadi and Alhomam (2019) also observed that $C$. indica APK-2 strain is not only a fast colonizer in vivo but also a rapid biomass producer in vitro conditions at a temperature of $30^{\circ} \mathrm{C}$.

The size and weight of sporophore and fruiting bodies of Calocybe indica were significantly affected with different spawn substrates. The results showed that the length $(6.28-8.73 \mathrm{~cm})$, diameter $(1.69-2.71 \mathrm{~cm})$ and 
weight (28.57-33.91 g) ranged significantly with varying treatments. The highest stipe weight was recorded with Paddy straw (33.91) whereas the lowest was recorded when coconut coir pith (28.57 g) was used as a substrate (Table 2). Singh et al., (2018) have also found similar results with APK-2 strain while growing it on different agrowastes in other parts of the country. Pileus to stipe ratio was more with sorghum stalk where the length of the pileus $(7.65 \mathrm{~cm})$ was lesser than the pileus diameter $(8.01 \mathrm{~cm})$ while in all other substrates, stipe length was more than the diameter of the pileus. Among the substrates, coconut coirpith recorded the least pileus to stipe ratio (0.79). Alam et al., (2010) also investigated the most suitable supplements and their levels for the commercial cultivation of milky white mushroom and revealed the superiority of paddy straw on its influence on sporophore characteristics.

From the present study, it can be concluded that preferential colonization of substrates and sporophore yield exhibited by Calocybe indica depends upon factors like per cent lignocellulosic composition of substrate material, which consists of cellulose, hemicelluloses, lignin and other phenolics that either favour or hinder the activity of mycelial growth. Secondly, the biodegradative potential of mycelium to grow on a particular substrate lies in its ability to degrade it, which in turn is decided by the repertoire of lignocellulolytic enzymes it possesses. It was therefore concluded that paddy straw as a substrate was found as best spawn substrate followed by maize stalk in respect of size (length of stipe, diameter of stipe and pileus) and weight of sporophores, yield and biological efficiency.

\section{References}

Alsowadi, Y.A. and Alhomam,S.A. (2019).
Effect of different temperature on biomass of milky mushroom (Calocybe indica). Int. Journal of Universal Science and technology 5 (1): 32-36.

Alam, N., Amin, R., Khair, A. and Lee, T.S. (2010). Influence of different supplements on the commercial cultivation of milky white mushroom. Bangladesh Mycobiology. 38 (3):184188

Biswas, S. and Singh, N.P. (2009). Evaluation of alternative substrate for milky mushroom. J Mycol Pl. Pathol, 39: 355357.

Chang, S.T. and Miles, P.G. (1989). Biology and Cultivation of Edible Mushrooms. Academic Press, London. pp. 265-274

Chauhan, S. and Pant, D.C. (1988). Effect of spawn substrates and storage conditions on sporophore production in Pleurotus sajor -caju. Indian J. Mycol. Pl. Pathol. 18 (3): 231-234.

Dakshayini, G. and Mallesha, B.C. (2018). Evaluation of substrate combinations for oyster and milky mushroom production. Mysore Journal of Agricultural Sciences; 52 (4): 698-709

Doshi, A., Munot, J.F. and Chakravarti, B.P. (1988). Nutritional status of an edible mushroom Calocybe indica $\mathrm{P} \& \mathrm{C}$. Indian J. Mycol. Pl. Pathol.18: 301-302.

Gitte, V.K., Priya, John. and Kotgire G. (2014). Selection of different substrates for cultivation of milky mushroom (Calocybe indica P\&C). Indian Journal of Traditional Knowledge. 13(2): 434436.

Krishnamurthy, A.S. and Muthusamy, M. (1997). Yield performance of $C$. indica on different substrates. Mushroom research 6: 29-32

Krishnamurthy, A.S. and Priyasharshini 2016. Physical, Chemical and Biological Properties of Casing Soil Used for Milky Mushroom (Calocybe indica 
P\&C) Production. Madras Agric. J., 103 (10-12): 338-343

Kumar, R., Singh, G. and Mishra P. (2013). Influence of different substrates and Environmental factors on yield of two strains of Calocybe indica. $\mathrm{J}$ Mycopathol. Res. 53(1):75-82

Lakshmipathy, G., Tayakumar, A., Abhilash, $M$.and Raj, S.P. (2011). Optimization of growth parameters for increased yield of the edible mushroom Calocybe indica. African J. Biotech. 11 (11): 7701-7710.

Pani, B.K. (2010). Evaluation of some substrates for the cultivation of white summer mushroom. Res J Agricultural Sci. 1: 357-359

Rawal, P. and Doshi, A. (2014). Evaluation of substrate for organic cultivation of milky mushroom. Periodic Research 2: 28-30

Senthilnambi, D., Eswaran, A. and Balabaskar, P. (2011). Impact of different spawn substrates on yield of Calocybe indica. African J. Agri. Res. 6(12): 3946-3948

Singh, M., Singh, AK. and Gautam, R.K. (2009). Effect of casing and supplementation on yield of milky mushroom (Calocybe indica). Indian Phytopath. 60(2):191-193

Thakur, M.P. and Singh, H.K. (2014). Advances in the cultivation technology of tropical mushrooms in India. JNKVV Res J. 48:120-35.

\section{How to cite this article:}

Sangeetha, A. and Rajappan, K. 2020. Substrate Comparison for Yield Maximization in White Milky Mushroom (Calocybe indica). Int.J.Curr.Microbiol.App.Sci. 9(07): 106-113. doi: https://doi.org/10.20546/ijcmas.2020.907.012 